\title{
Role of Medical Records Management Practice in Improving Decision Making in University Hospital
}

Nora Aslinda Mohd Amin, Saiful Farik Mat Yatin, Jafalizan Md Jali, Noor Zaidi Sahid, Shamila Mohamed Shuhidan, Siti Arpah Noordin, Wan Abd Malek Wan Abdullah

To Link this Article: http://dx.doi.org/10.6007/IJARBSS/v10-i11/8193

DOI:10.6007/IJARBSS/v10-i11/8193

Received: 15 September 2020, Revised: 07 October 2020, Accepted: 30 October 2020

Published Online: 25 November 2020

In-Text Citation: (Amin, et. al., 2020)

To Cite this Article: Amin, N. A. M., Yatin, S. F. M., Jali, J. M., Sahid, N. Z., Shuhidan, S. M., Noordin, S. A., \& Abdullah, W. A. M. W. (2020). Role of Medical Records Management Practice in Improving Decision Making in University Hospital. International Journal of Academic Research in Business and Social Sciences. 10(11), 1160-1175.

Copyright: (c) 2020 The Author(s)

Published by Human Resource Management Academic Research Society (www.hrmars.com)

This article is published under the Creative Commons Attribution (CC BY 4.0) license. Anyone may reproduce, distribute, translate and create derivative works of this article (for both commercial and non-commercial purposes), subject to full attribution to the original publication and authors. The full terms of this license may be seen

at: http://creativecommons.org/licences/by/4.0/legalcode

Vol. 10, No. 11, 2020, Pg. 1160 - 1175

Full Terms \& Conditions of access and use can be found at http://hrmars.com/index.php/pages/detail/publication-ethics 


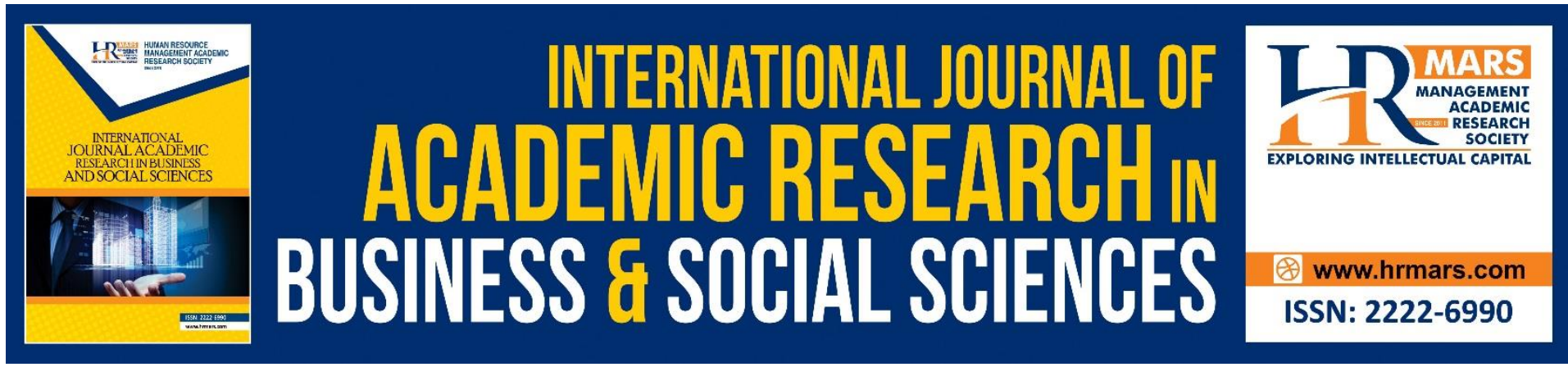

\title{
Role of Medical Records Management Practice in Improving Decision Making in University Hospital
}

\author{
${ }^{1}$ Nora Aslinda Mohd Amin, ${ }^{2,3}$ Saiful Farik Mat Yatin, ${ }^{2}$ Jafalizan \\ Md Jali, Noor Zaidi Sahid, ${ }^{2}$ Shamila Mohamed Shuhidan, ${ }^{2}$ Siti \\ Arpah Noordin, ${ }^{2}$ Wan Abd Malek Wan Abdullah \\ ${ }^{1}$ Health Information Division, Hospital Canselor Tuanku Muhriz, UKM, Kuala Lumpur, \\ Malaysia, ${ }^{2}$ Faculty of Information Management, Universiti Teknologi MARA (UiTM) \\ Selangor, Malaysia, ${ }^{3}$ Members of Advanced Analytics Engineering Center (AAEC), UiTM \\ Malaysia \\ Email: noraaslinda23@gmail.com,farik@uitm.edu.my
}

\begin{abstract}
Hospitals deal with the life and health of their patients. Good medical care relies on welltrained doctors and nurses and on high-quality facilities and equipment. Without accurate, comprehensive up-to-date and accessible medical records, medical personnel may not offer the best treatment or may in fact misdiagnose a condition, which can have serious consequences. The objectives of the study are to identify medical record management in university hospital associated with good practice in managing records, to assess the staff skill in managing medical records appropriately and to see medical record management program contribute for quality decision making. The study applies quantitative method approach with use structured questionnaire. A cluster sampling technique was used to classify the whole hospital into nine departments (clusters). The researcher purposively selected 90 health staff and a records staff to participate in this study. Researcher found that completeness physical note and nursing note of patient and also use and archive lifecycle do not associate with good practice in managing medical records. From the study, it is clear that most of the medical record officers have insight into personal skills and competencies about medical record. Researcher found that for second research question, medical record officers have the right level of staff skill to manage medical records appropriately. From the survey on decision making factor, the finding are, all factor in doing decision making are significant. Good medical record management program associated with quality of decision making. Misfiling and missing files, shortage of records staff and poor staff knowledge are the three main problems that affect the hospital in their quest to managing records effectively and making decisions. So that, researcher recommendation are to make adoption of an integrated Electronic Records Management System, more training for records staff, conducive storage and enlarge storage location, adequate records staff and more alert about security issues.
\end{abstract}


Keywords: Record, Medical Record, Records Management, Decision Making, Role of Medical Records

\section{Introduction}

X-rays, specimens, drug records and patient registers, must be well managed to make patients to be protected. Similarly, good medical records care ensures the hospital's administration runs smoothly: unneeded records to be transferred or destroyed regularly by keeping storage areas clear and accessible; and key records to be found quickly by saving time and resources. Medical record is the only history of achievement, the only measurement of work being done by the medical and nursing staff, the only record of progress of the patient, and it is the source of information for many purposes. Taking into consideration the benefits of medical records, this paper systematically discusses the concept, significance and challenges of medical records as a whole.

Healthcare is a complex that includes organizations, people, institutions, and actors who seek to promote, maintain, and restore physical health. Decision making in healthcare is challenging due to its complexity, yet it is essential because of the high stakes: doctors must quickly choose the right course of action when the lives of their patients are in danger, and hospital leaders must deliver quality care with limited resources while generating sustainable revenues. Policy-makers must understand competing priorities, comply with existing legislation, and manage competition for scarce resources while designing policies that affect the entire healthcare system.

\section{Background Study}

Many acknowledge that there has been an information explosion in the health services over the last few decades. The existence mountain of information provides a myth of certainty for the patient, the public and perhaps for health care policy-makers. Certainty is an illusion. In most professional spheres the expert is more critical of the available evidence, than is the lay person. Hopefully, clinicians are taught to be more critical than patients but they are faced with a dilemma. They appear to be very well informed yet are acutely aware of the fallibility of the information that is expected to guide their practice (West, 2002). Medical decisionmaking (MDM) mistakes are common (Pohlig, 2014). Decision-making in hospitals has evolved from being opinion-based to being based on sound scientific evidence. This decision-making is recognized as evidence-based practice. Perpetual publication of new evidence combined with the demands of everyday practice makes it difficult for health professionals to keep up to date (Malykh \& Rudetskiy, 2018).

Zegers (2011) stated in his study that the primary aim of recording information in patient's medical records is to support the delivery of good care, clinical decision making, communication between healthcare workers and continuity of care. One of the most important decisions a physician has to make based on medical information in an emergency department (ED) is whether to admit a patient or not. Admissions and readmissions are a key measure of healthcare efficiency (Silow-Carroll, 2011). If a patient is readmitted shortly after a hospital stay, this might indicate that the hospital discharged the patient without proper care or the right diagnosis. In addition, existing scales have shown that unnecessary shortterm admissions can also be reduced and even eliminated if physicians have access to proper medical history (Ben-Assuli, Leshno \& Shabtai, 2012). 
The life cycle of patient's medical record begins with its creation, maintenance and use and ends with disposition. The retention period for medical records are different for Obstetric and Paediatrics records whereby they are required to be kept for at least twenty-one (21) years as compared to other medical records which has a retention period of only seven (7) years (National Archive Act, 2003).

\section{Records Management Problems}

The medical record was to be used for further treatment by the patient's private doctor to conduct radiotherapy for the patient, but before that he needed medical records to get information about the patient's medical history. However, if the medical records and X-rays of the patient could not be found, this resulted, the doctor being unable to proceed because fear of giving the wrong treatment to patient's and the life of the patient was at stake as a result of unavailability of records (Marutha, 2017).

At a university hospital in Iran, researchers documented that most medical records in the hospital were incomplete and incompatible with established standards. Incomplete charting was attributed to poor handwriting, lack of documentation of requested information (e.g. laboratory results) and missing pages. Hospital staff appeared unaware of the importance of medical records to the treatment and follow-up of patients (Pourasghar, Malekafazli, Kazemi, 2008).

\section{Incompetent Staff Skills}

Record Management practices are not considered as priority areas in organisations, and invariably records are manned by staffs who have very limited experience or skills in managing records (Tale \& Alefaio, 2011). For effective and efficient management of hospital records, there is the need for hospitals to have records personnel who have the requisite skills to manage the records that have been created in the course of their business (Mensah, 2011). Records keeping in health institutions had been plagued by factors such as poor staff skills, incompetent records personnel and low prioritization of records management in relation to other functions (Afolabi, 2004; Egwunyenga, 2009).

\section{Poor Decision Making}

In a situation where the organization does not value the benefits of sound record keeping practices, the ramifications are poor healthcare delivery, long patient waiting time, poor decisions and weak corporate memory. In the end, healthcare providers end up not rendering certain services because the patient's history is not contained or captured in medical files (Hitler, 2013; Marutha, 2011)

Healthcare institutions do not recognize an effective records management system as a key mechanism for attaining their desired goals (Acheampong, 2012). Absence of a wellfunctioning records management system, decision are made without detailed information (Ngoepe, 2004; Wamukoya \& Mutula, 2005).

\section{Literature Review}

\section{Record Management Program}

Ohsfeldt (2005); Shekelle, Morton \& Keeler, (2006); Thompson \& Brailer (2004) concur that accurate and comprehensive hospital records lead to quality patient care, increase in efficiency of care, reduce medical errors, improve access to patient data, confidentiality of 
patients and quality decision making. Furthermore, the National Archives of Malaysia (2003) declares that the phase provides a suitable environment for easy access to timely, accurate and available information in a record. Furthermore medical records must be securely maintained to prevent unauthorized access, alteration, damage or removal. An efficient management of hospital records also expedite decision making, inform future decisions, increase accountability of decision makers, produce evidence in medico-legal issues, support perpetuity of the facility and improve service delivery (Akor \& Udensi, 2013). Palmer \& Marlize (2000) viewed accountability as a particularly crucial governance element and refers to holding officials of organizations responsible for their actions. Without records, there can be no accountability and no rule of law. A good records management system is essential for supporting financial management, accountability and transparency. Proper health records management is significant to government realization and achievement of their goals such Adu Freda (2014), as the rule of law, accountability, management of state resources, and protection of entitlements of its citizens as well as enhancing foreign relations (Kemoni \& Ngulube, 2008).

In the opinion of the importance of records management is increasingly being recognized in organizations. It is therefore the responsibility of records managers to ensure that they gain the attention of decision-makers in their organizations. Gaining recognition is all about convincing management of the role of records management as enabling unit in an organization. Employees require information in order to carry out their official duties and responsibilities efficiently and effectively in a transparent manner. Records represent major sources of information and are almost the only reliable and legally verifiable source of data that can serve as evidence of decisions, actions and transactions in an organization (Tagbotor, Adzido \& Agbanu 2015). Northwest Territories (2002) stated that the role of records management is to ensure that members of staff involved in different operations have the information they need, when necessary and an organization creates and keeps records so that it can keep track of what its members have done and what was decided.

Shepherd \& Yeo (2003) point out three main qualities of good records: First and foremost, organizations use records in the conduct of business transactions and to enhance decision making. Secondly, organizations use records to support accountability and legal and financial obligations. Lastly, records may be used for cultural purposes and research, to promote awareness and understanding of corporate history. Ryan (2010) states that the evidential value of a record can only exist if the content, structure and context are preserved, meaning that without preservation, there won't be any record. In support of Cowling (2003), in the conduct of their business activity, organizations and individuals often need to consult records of their previous activities and decisions, for example to provide background information, establish the existence of a precedent or to substantiate or refute a claim or allegation. Records in this case are of utmost importance for an organization's administrative function. An organization needs long-term documentary evidence of the way in which funds were obtained, allocated, controlled and expended (budget). This includes budget records, which provide evidence of how income and expenditure were planned, and various accounting records documenting financial transactions. Legal records provide evidence of contractual obligations, duties and privileges agreed upon by governments' organizations or individuals. They provide record of matters such as property titles, charitable status and other legal and civil rights. They may be preserved as evidence of the decisions of governments, courts and 
other bodies or as the source of the authority for action taken by organizations or individuals. The essence of records in organizations are for formulating and implementing policies, keeping track of day-to-day activities, achieving consistency in decision making, providing quality service to individuals and achieving greater efficiency (Kemoni, Ngulube \& Stilwell, 2007).

Medical record completeness is a key performance indicator that is related with delivery of healthcare services in the hospital (Tola, 2017). Wong (2009) rated a medical record complete if it included the following items: medical record number on each page, patient information in the record, physician note, nursing note for inpatient, medication record if ordered, lab result if ordered and radiology result if ordered. Every entry in the medical record should be dated, timed ( $24 \mathrm{H}$ clock) and legible. Each should be signed by the person making the entry and should be made as soon as possible after the event to be documented (e.g. change in clinical state, ward round, investigation etc) and before the relevant staff member goes off duty (Mathioudakis, 2016).

There are many causes of the problem of poor records management practices stated by the State of Montana, Montana Historical Society (2002); Hounsome (2001):

- $\quad$ Lack of records management policies and procedures.

- $\quad$ Lack of qualified staff such as a records manager and archivist.

- Records management costs that are not immediately apparent. Cost may only become significant over a period of time and thus not attract management's attention.

- Limited resources to implement a system according to requirements (legislation. Number of staff and other resource adequate or not.

In a word of change, information has become the most dominant resource in the success of organizations and at the same time, organization have to meet increasing regulatory and legal requirements. The management of recorded information, irrespective of form or format, is more vital to organizations than ever before (Sanderson \& Ward, 2003). Tagbotor, Adzido \& Agbanu (2015) in their study found that records management policy provides guidance in establishing and maintaining records management system. Lack of it and non-compliance are the main causes of poor records management.

Just like a living organism, records have a life cycle as signified by their creation, use and disposal after their survival period. Shepherd \& Yeo (2003) admits that the records life cycle is in common use. Furthermore the concept indicates that records are not static, but are subject to life related to that of a biological organism. Hence the records are born; live through youth and old age and then die. Hare \& McLeod (1997) claims that the creation stage phase is the root of the life span of the record. It is the stage where records and information are initially created or acquired. Records management seeks to efficiently and systematically control the lifecycle (creation, capture, use, maintenance, archive or disposal) of records that are daily generated as a result of business daily activities and transactions. This signifies that records management is based on the principles of daily review and controlled retention or destruction of records with the general aim of ensuring legal and regulatory compliance and corporate accountability (Chinyemba \& Ngulube, 2005).

The maintenance and use stage of a life cycle covers distribution, active storage, security and updating of the records throughout the organization. It is the stage where records are used 
and shared. They must be stored in a secure environment, the degree of security reflecting the sensitivity and importance of the contents. Where records are migrated across changes in technology, the evidence preserved must remain authentic and accurate (National Archives of Scotland, 2015). Records must therefore, be protected and kept in a safe place to ensure good access as and when needed. Tavakoli \& Jahanbakhs (2013) believes that retention of medical record is an important matter in a health care facility. Medical records must be maintained by a facility to support patient care; meet legal and regulatory requirements; achieve accreditation; allow research, education, and reimbursement; and support facility administration. The duration of record retention differs for the various types of records kept such as laboratory data, radiology reports and films, fetal monitor strips, birth certificates, Master Patient Indexes) and for different facilities like physicians offices in hospitals. Medical records retention as well as its disposal or destruction is important considering challenges usually associated with space and storage or records. Medical records personnel should therefore, maintain a specific program or have a policy in place to retain and destroy the records to avoid these challenges

Records disposal is a stage of a life cycle which refers to the transfer of the record to a repository for safe keeping for a set period of time. Records could also be sent to the archives for permanent storage. Before the records could be disposed they go through an appraisal system. Disposal could be through safe keeping by transferring records to the archives or through permanent destruction. Records reach their inactive phase when their primary value to the organization lapses. The National Archives of Malaysia (2003) mentioned that records are disposed at the stage when they have reached end of their life cycle. In disposing inactive records consideration need to be made concerning the value of information the record contains. The life cycle therefore draws to the conclusion that records are kept initially for organizational purposes and that they may be relocated into archival custody when because of time are no longer into active use as indicated on Figure 1 below:-

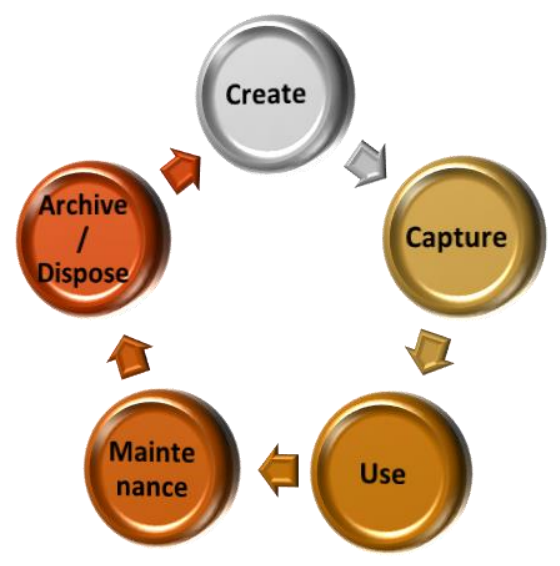

Figure 1: Lifecycle of record

\section{Staff Skills}

All staff have a responsibility to manage records effectively, through the documentation of all decisions and actions made; the effective maintenance of records throughout their lifecycle, including access, tracking and storage of records; the timely review of records and their ultimate disposal, whether this be transfer to archive for permanent preservation, 
confidential destruction or recycling. It is recommended that the records manager has the following professional skills and competencies:

- a sound knowledge of records management theory and practice, including standards and best practice;

- an ability to apply and adapt records management standards and best practice effectively in the organisation's context;

- an understanding and ability to establish various records management tools and techniques;

- a good knowledge of records management software applications and their use;

- experience or knowledge of other organisations' records management systems, obtained through regular liaison with peers;

- can do observation of other organisation's experiences;

- An ability to interpret best practice standards, apply locally and provide accurate and effective advice and guidance to colleagues (National Records of Scotland, 2016)

Qualified records management staff in an organisation ensures that records management work is carried out efficiently. Employees need to be capacitated with the knowledge and skills to develop and maintain the records management programme. The knowledge required should cover all the processes of records management (Chinyemba \& Ngulube, 2005). The records manager is also expected to have the following personal skills and competencies:

- clear, confident and effective communication skills, both verbally and in writing;

- an ability to communicate and get on well with colleagues at all levels;

- enthusiasm and is pro-active;

- a positive "can-do" attitude;

- completes tasks through to their conclusion;

- works effectively in a team environment, including in a leadership role;

- flexibility and an adaptable outlook, including the ability to respond to changing needs and different situations;

- effective advisory and influencing skills;

- can deliver effective presentations and training to an audience;

- shares knowledge and experience;

- good analytical skills;

- marketing and promotional awareness, skills and abilities;

- personal and professional integrity;

- ability to develop and maintain a wide network of professional contacts;

- keeps up to date with professional developments and actively participates within the professional community (National Records of Scotland, 2016)

The knowledge and competence of healthcare providers and their contributions to the creation, use, maintenance and preservation of records cannot be underestimated if health care and decisions are to improve (Mensah, 2011). The following knowledge and skills are required by staff with recordkeeping responsibilities:

- a good understanding of records management issues and best practice and how they relate to the organisation;

- an ability to adapt to and support others in the development and introduction of new recordkeeping practices and procedures; 
- an ability to assess current recordkeeping systems and provide feedback to the records manager on their strengths and areas for improvement;

- an ability to communicate effectively at all levels of the organisation;

- an ability to recognise potential issues in relation to records management and communicate these to the relevant staff;

- enthusiasm and a proactive approach to improving recordkeeping practices;

- a good understanding of the legislative environment within which they operate;

- an ability to contribute to the development and implementation of new records management systems and solutions;

- an understanding of how good records management can lead to improved business efficiency and working practices, as well as other organisational benefits;

- flexible and adaptable to change;

- an ability to apply records management principles and practices to own work role and work of others;

- an ability to monitor and feedback compliance with policies/procedures;

- an understanding of different types of risk, in relation to recordkeeping;

- an ability to work under pressure and to deadlines;

- accuracy and attention to detail;

- problem-solving skills;

- an awareness of information, advice and guidance sources (National Records of Scotland, 2016)

The records manager's primary role will be to develop and implement records management policies, procedure and guidance, and to provide advice on recordkeeping issues (National Records of Scotland, 2016). Tagbotor, Adzido \& Agbanu (2015) opines that lack of training in records management can hamper an organization's performance. If employees do not have guidelines on how to operate and not trained about how to use filing systems, productivity cannot be improved.

\section{Decision Making}

Decisions made at the right or opportune time leads to achieving organizational goals such as high productivity, profitability and competitive advantage whiles wrong timing of decisions sometimes waste organizational resources (Darwish, 2014). Decision making is vital for every organization that strives to mitigate risk, achieve organizational performance and improve service delivery (Tagbotor, Adzido \& Agbanu, 2015). Organizations' decision making is a complex process that must be understood and interpreted completely before it can be practiced effectively (Nooraie, 2012). In hospitals, for a decision to be made on records generated, there is the need to interpret such information in order to inform the decision. This implies the ability to interpret available information influences the decision to make (Darwish, 2014).

Data are correct, genuine, reliable and certified. This implies that there is no inherent limitation, free from errors and mistakes. Inaccurate information is likely to result in poor decisions likewise accurate information can also result in good decision (Ge \& Helfert, 2006). Medical record-keeping quality is part of the hospital work environment besides other aspects like physician-nurse relations, nurse participation in decision making and organizational priorities on care quality (Aiken, 2012). One of the most important factors in making decisions is the information or records. This is due to the fact that having detailed, 
accurate and timely information hasten decision making likewise scanty, inaccurate and poor timing result in making wrong decisions (Darwish, 2014). The absence of patient record components was associated with lower rates of AEs. Thus, missing record components lead to an underestimation of AEs in record review studies. In contrast, poor quality (completeness, readability and adequacy) of the available patient information was associated with higher rates of AEs. The quality of the recorded information in patient records seems to be a predictor of the quality of care (Zegers, 2011).

This refers to the timing in which decisions are made (Darwish, 2014). Decisions made at the right or opportune time leads to achieving organizational goals such as high productivity, profitability and competitive advantage. A study by Stephenson (2012) disclosed that not having enough time to decide on what to do at any particular point in time has a bearing on the quality of a decision. The author further posited that decision made under pressure could be very disastrous, as it only solves an immediate problem but could lead to a bigger problem. By documenting all relevant clinical information you are recording this information for future reference. Remember, if you did not write it down, it did not happen. Continuity in clinical notes is of vital importance to patient care as, in the current medical environment, many different healthcare professionals are involved in the treatment of a single patient. Making sure that clinical notes are up to date and completed accurately with sufficient information will ensure that the proper information is provided to all relevant healthcare workers and will aid them in potential future decisions (Mathioudakis, 2016). They add that thus, in a court of law, it does not matter if you have done your best for your patient unless you have accurately documented this fact. However, the legal burden of proof can depend on the specific setting and circumstances in which the notes are being scrutinised.

Darwish, (2014) put forward that having timely information and effective records management systems expedite decision making and thus, reduce the likelihood of making poor decisions. His survey in the Iranian airports company disclosed that the practice of an effective records management system, a simple and a functional electronic filing system increases the speed at which files or records are retrieved and subsequently, influences the speed at which clinical and administrative decisions are made in organizations. In the event where the records management systems are effective, decisions are made quicker to meet the ongoing and future needs of the organization. On the other hand, ineffective records management systems retard the speed at which decisions are made. Decisions made at the right or opportune time leads to achieving organizational goals such as high productivity, profitability and competitive advantage whiles wrong timing of decisions sometimes waste organizational resources. Many managers simply need effective records management systems and guidance to make quality decisions based on reliable evidence.

However, there is no systematic guarantee that the evidence available to managers of organizations is reliable and genuine to make such decisions (Pfeffer \& Sutton, 2006). A survey conducted by Akor \& Udensi (2013); Mampe \& Kalusopa (2012) revealed that effective records management systems facilitate timely and quality decision making, inform future decisions and fast track service delivery. Simon Fraser University (2007) argues that records management does not only allow an organization to function on a daily basis, but also to fulfill its legal and financial requirements since up-to-date information of activities is available as reference point. Records that are managed effectively facilitate timely and efficient decision 
making, inform future decisions, produce evidence in litigation cases, increase accountability of decision makers and fast track an efficient service delivery (Akor \& Udensi, 2013; Kemoni \& Wamukoya, 2005; Mampe \& Kalusopa, 2012). With effective records management, organizations such as hospitals benefit from reduced risks from medico-legal or regulatory challenges by finding and producing the relevant evidence contained in records. In effect, the hospital can be assured that there is a full disclosure of information for decision-makers to rely on in the course of carrying out their duties, thus improving the quality of decision making, long term planning and delivering efficient health care to the public (Ojo, 2009). In study by Amo Justice (2016), stated that incomplete information affected the kind of decisions the units wanted to make. Many of our quality and safety measures are riskstratified. Thorough documentation with the appropriate coding of the problem list will accurately reflect the overall state of the patient. The quality and safety measures affect payments directed to hospitals. As requirements for surgeon-specific data increase, clear documentation with ICD-10 could affect potential future pay-for-performance programs If a surgeon under-codes a case, then the observed ratio may fall below the expected average of his or her colleagues (Megan, 2015).

\section{Findings}

With the 90 questionnaires distributed to one of university hospital, 90 questionnaires were returned by respondents which represented $100 \%$ of questionnaire response rate. The ages of the participants ranged from 18 to 60 years old. The majority participant age was 24 to 34 years which represented (34.4\%) follow by age group between 35 to 44 years and 45 to 54 years with (18.9\%). A sizeable number (41\%) were males whiles the remaining number (49\%) were females. That is implies that a slightly higher number of females participated in the survey than males. Majority (31\%) of the respondents had attained Bachelor whiles a large number (24\%) had acquired Doctor of Philosophy (PhD). Moreover, a few (3\%) of the participants had attained secondary school. This shows that almost every staff at the hospital has acquired some form of education.

\section{Staff Skills}

From the finding, researcher found that medical record management in university hospital associated with good practice in managing records. Beside that, researcher found completeness physical note and nursing note of patient and also use and archive lifecycle do not associate with good practice in managing medical records. It is clear that most of the medical record officers has insight into personal skills and competencies about medical record. They had an ability to communicate and get on well with colleagues at all levels; enthusiasm and pro-active, positive "can-do" attitude; completes task through to their conclusion; work effectively in a team environment, including in a leadership role; flexibility and an adaptable outlook, including the ability to respond to changing needs and different situations. Not only that, medical record officers also had effective advisory and influencing skills; can deliver an effective presentations and training to an audience and they have shares knowledge and experience. The important skills are they have personal and professional integrity,; ability to develop and maintain a wide network of professional contacts and keep up to date with professional developments and actively participates within the professional community. For good analytics skills; and have marketing and promotional awareness, skills and abilities are do not significant with personal skills and competencies about medical record 
which is contradict with National Records of Scotland, (2016). From the study, proved medical record officers have the right level of staff skill to manage medical records appropriately.

\section{Decision Making}

Medical records generated at university hospital are correct, genuine, reliable, certified, no inherent limitation, free from errors and mistakes, detailed, accurate and timely. This will help the decision maker improve their decision making. From the survey on decision making factor, researcher found that the finding is same with the literature review which is all factor in doing decision making are significant

\section{Challenges in Managing Records and Making Decisions}

The study reveals that issues of misfiling and missing files, shortage of records staff and poor staff knowledge are the three main problems that affect the university hospital in their quest to managing records effectively and making decisions. The issue of missing files and misfiling can be setbacks for the hospital if the staffs want to retrieve files to commence daily activities or make decisions. This goes in line with the literature that for records management systems to improve decisions, issues such as missing files, misfiling, inadequate storage location, and poor staff knowledge need to be addressed adequately (Ge \& Helfert, 2006; Liakopoulou, 2013). This shows that the hospital is affected by its decision making processes. Other than that, respondent also mention that staffs in university hospital with poor knowledge of using medical record and lack of knowledge using the computer. Moreover, money, budget, management support, staffs especially clinicians cooperation and understanding/ knowledge of medical record management are the challenges in handling medical records.

\section{Conclusion}

The study showed that the hospital has a records management programme that outlines how records are created, captured, used, maintained, preserved and disposed. Furthermore, the university hospital is guided by guidelines and procedural manuals designed by Ministry of Health and National Archives of Malaysia in the management of records. Last but not least, the kind of records keeping practice adopted by the university hospital has an influence on decision accuracy, decision timeliness and decision commitment. However, poor staff knowledge, inadequate records professionals, missing files, damaged files, inadequate filing space and inadequate hardware among other challenges affect managing records at university hospital.

\section{Acknowledgement}

This article is financially supported by:

1. Faculty of Information Management, UiTM Selangor, Malaysia

2. Advanced Analytics Engineering Center (AAEC), UiTM Malaysia

\section{References}

Acheampong, E. K. (2012). Electronic Health Record System: A Survey in Ghanaian Hospitals. Journal of Health \& Medical Informatics, 03(02). doi:10.4172/scientificreports.164

Adu Freda. (2014). Assessment Of Records Management Practices Among The Administrative Staff Of University Of Education, Winneba - Kumasi (UEW-K) and Mampong (UEW-M) Campuses, (Master's Thesis, Kwame Nkrumah University of Science and Technology). Retrieved

from http://ir.knust.edu.gh/bitstream/123456789/7540/1/Adu\%20Freda.pdf 
Afolabi, M. (2004). Education Training Archivists and Records Managers in Africa, Annual Conference of the Society of Nigeria Archivists, 61-67. Lagos: SNA.

Ajami, S., Ketabi, S., \& Torabiyan, F. (2015). Performance improvement indicators of the Medical Records Department and Information Technology (IT) in hospitals. Pakistan Journal of Medical Sciences, 31(3), 717-720. http://doi.org/10.12669/pjms.313.8005

Akor, U. P., \& Udensi, J. (2013). An Assessment of Records Management System in establishment division of two Universities in Nigeria. International Letters of Social and Humanistic Sciences, 13, 97-109.

Aiken, L. H., Sermeus, W., Van den Heede, K., Sloane, D. M., Busse, R., McKee, M., ... KutneyLee, A. (2012). Patient safety, satisfaction, and quality of hospital care: cross sectional surveys of nurses and patients in 12 countries in Europe and the United States. BMJ, 344 (Mar 2012), e1717-e1717. doi:10.1136/bmj.e1717

Amo Justice. (2016). The Role Of Records Management Practices In Improving Decision Making In Public Hospitals: The Case Of Ashanti Bekwai Municipal Hospital (Master's Thesis). University of Ghana.

Ben-Assuli, O., Leshno, M., \& Shabtai, I. (2012). Using Electronic Medical Record Systems for Admission Decisions in Emergency Departments: Examining the crowdedness effect. Journal of Medical Systems, 36(6), 3795-3803. doi:10.1007/s10916-012-98520

Chinyemba, A., \& Ngulube, P. (2005). Managing records at higher education institutions: A case study of the University of KwaZulu-Natal, Pietermaritzburg Campus. SA Journal of Information Management, 7(1), 1-19. doi:10.4102/sajim.v7i1.250

Confidentiality Of Medical Records Information : Who's Responsibility? (2016, December 5). Retrieved from http://www.myhealth.gov.my/en/confidentiality-of-medical-recordsinformation-whos-responsibility/

Cowling, C. (2003). Records management manual. London: University of London.

Darwish, H., Saki, N., Sahraei, M., Zakrifar, F., \& Talebi, S. M. (2014). Effects of Automated Office Systems (automation) on improve decision making of staff managers (at the airports company of country). Journal of Educational and Management Studies, 4(3), 554-564

Egwunyenga, E. J. (2009). Record keeping in Universities: Associated problems and management options in South West Geo-Political zone of Nigeria. International Journal Education Science, 1(2), 109-113

Ge, M., \& Helfert, M. (2006). A Framework to assess decision quality using information quality dimensions. $\quad$ Retrieved from http://www.researchgate.net/publication/220918695_A_Framework_to_Assess_De cision_Quality_Using_Information_Quality_Dimensions

Hare, C., \& McLeod, L. (1997). Developing a records management programme. London: Aslib. Hitler, D. S. (2013). The Contribution of Information Management to Administrative Decision Making in Kinondoni Municipal Council (MPA Thesis). Mzumbe University

Hounsome, C. (2001). The records management challenges of amalgamation. Municipal Monitor, June/July: 1-7.

Hospital Canselor Tuanku Muhriz UKM (HCTM). (n.d.). Retrieved from https://www.ppukm.ukm.my/language/en/

Kemoni, H. N., and Wamukoya, J. (2005). Preparing for the Management of Electronic Records at Moi University, Kenya: A case study. African Journal of Library, Archives and Information Science, 10(10), 125-138. 
Kemoni, H. N., Ngulube, P., \& Stilwell, C. (2007). Public Records and Archives as Tools for Good Governance: Reflections Within the Recordkeeping Scholarly and Practitioner Communities. ESARBICA Journal: Journal of the Eastern and Southern Africa Regional Branch of the International Council on Archives, 26(1). doi:10.4314/esarjo.v26i1.31012

Kemoni, H., \& Ngulube, P. (2008). Relationship between Records Management, Public Service Delivery and the Attainment of the United Nations Millennium Development Goals in Kenya. Information Development, 24(4), 296-306. doi:10.1177/0266666908098074

Liakopoulou, M. (2013). Investigating Motivational Factors Influencing Pre-Service Teachers' Choice of Profession and Their Personal Theories of Teaching and Learning. Multilingual Academic Journal of Education and Social Sciences, 1(1), 101-118.

Making Better Medical Decisions. (2016). Retrieved from https://www.psychologytoday.com/us/blog/modern-medicine/201609/makingbetter-medical-decisions

Malaysian Medical Council. (2006). Medical Records and Medical Reports, Guideline of The Malaysian Medical Council, MMC Guideline 002/2006

Malykh, V. L., and Rudetskiy, S. V. (2018). Approaches to Medical Decision-Making Based on Big Clinical Data, Journal of Healthcare Engineering, Vol. 2018, Article ID 3917659, 10 pages, 2018. https://doi.org/10.1155/2018/3917659.

Mampe, G., and Kalusopa, P. (2012). Records Management and Service Delivery: The Case of Department of Corporate Services in the Ministry of Health. Journal of the South African Society of Archivists, 45, 2-23.

Marutha, S. N. (2011). Records Management in support of Service Delivery in the Public Health Sector of the Limpopo Province in South Africa (Master of Information Science). University of South Africa. Retrieved from http://uir.unisa.ac.za/bitstream/handle/10500/5737/thesis_marutha_n.pdf?sequenc $\mathrm{e}=1$

Marutha, N. S. (2017). A framework to embed medical records management into the healthcare service delivery in Limpopo Province of South Africa, PhD Thesis, University of South Africa

Mathioudakis, A., Rousalova, I., Gagnat, A. A., Saad, N., \& Hardavella, G. (2016). How to keep good clinical records. Breathe (Sheffield, England), 12(4), 369-373.

Mensah, M. (2011). Organizational commitment of medical records personnel at the Korle-Bu teaching hospital, Unpublished MA dissertation, University of Ghana, Legon.

National Archive Act 2003. (2003). Undang-undang Malaysia Akta 629. Retrieved July, 2018, from: http://www2.arkib.gov.my/borang/Akta_Arkib_Negara_2003.pdf

National Records of Scotland. (2016). Records Management Competency Framework July 2016, (July).

Ngoepe, M. S. (2004). Accountability, Transparency and Good Governance: the National Archives and Records Services of South Africa's role in helping Government to better Service Delivery to the South Africans. Retrieved from http://www.liasa.org.za/conferences/conferences2004/papers/LIASA_Conference_2 004_Ngoepe.pdf

Nooraie, M. (2012). Factors Influencing Strategic Decision-Making Processes. International Journal of Academic Research in Business and Social Sci, 2(7), 405-429.

Northwest Territories. (2002). What is Records Management? Records Management Bulletin, (3), 1-2. 
Ohsfeldt, R. L. (2005). Implementation of Hospital Computerized Physician Order Entry Systems in a Rural State: Feasibility and Financial Impact. Journal of the American Medical Informatics Association, 12(1), 20-27. doi:10.1197/jamia.m1553

Ojo, T. (2009). Communication Networking: ICT and Health Information in Africa. Information Development, 22(2), 94-101

Palmer, M. (2000). Records management and accountability versus corruption, fraud and maladministration. Records Management Journal. $10.61-72$. 10.1108/EUM0000000007256

Pfeffer, J., and Sutton, R. I. (2006). Hard Facts, Dangerous Half-truths, and Total Nonsense Profiting from Evidence-Based Management. Boston, MA: Harvard Business School Press.

Pourasghar, F., Malekafzali, H., Kazemi, A. (2008). What they fill in today, may not be useful tomorrow: lessons learned from studying medical records at the Womens Hospital in Tabriz, Iran. BMC Public Health 2008;8:139.

Pohlig, C. (2014). Practice economics medical decision-making: Avoid these common coding $\&$ documentation mistakes.

Ryan, D. (2010). What is the essence of records management? Records Management Journal, 20(1), 117-123. doi:10.1108/09565691011039889

Sanderson, M., \& Ward, S. (2003). Records management mission critical. Library and Information update, October, 1-7. Retrieved December 2, 2018 from www.cilip.org.uk

Shekelle, P. G., Morton, S. C., \& Keeler, E. B. (2006). Costs and Benefits of Health Information Technology. doi:10.23970/ahrqepcerta132

Shepherd, E. and Yeo, G. (2003). Managing Records: A Handbook of Principles and Practice. Facet Publishing, London.

Silow-Carrol, S., Edwards, N. J., and Lashbrook, A. (2011). Reducing hospital readmissions: Lessons from top-performing hospitals, Care Management (17)5, 14-31.

Simon Fraser University. (2007). What's Records Management? Bumaby B.C. Canada.

State of Montana Historical Society. (2002). Performance audit report: State government records management. Legislative audit division: Helena. Retrieved March 8, 2014 from leg.state.mt.us.

Stephenson, C. B. ( 2012). What causes top management teams to make poor strategic decisions?(Doctoral Thesis). Southern Cross University, Lismore, NSW. Retrieved from http://epubs.scu.edu.au/theses/280/

Tale, S., and Alefaio, O. (2011). "Records management in developing countries: challenges and threats - towards a realistic plan", Association of Commonwealth Archivist and Records Managers. (ACARM) Newsletters, No. 37, available at:

www.acarm.org/documents/issue37/37.6\%20Records\%20Management\%20in\%20Developin g\%20countries\%20-\% 20challenges\%20and\%20threats.pdf.

Tagbotor, D. P., Adzido, R. Y., \& Agbanu, P. G. (2015). Analysis of Records Management and Organizational Performance. International Journal of Academic Research in Accounting, Finance and Management Sciences, 5(2). doi:10.6007/ijarafms/v5i2/1557

Tavakoli, N., \& Jahanbakhsh, M. (2013). Investigation of retention and destruction process of medical records in the hospitals and codifying appropriate guidelines. Journal of Education and Health Promotion, 2(1), 17. doi:10.4103/2277-9531.112687 
Thompson, T. G., and Brailer, D. J. (2004). The Decade of Health Information Technology: Delivering Consumer Centric and Information-rich Health Care. Washington, D.C.: U.S. Department of Health \& Human Services

Tola, K., Abebe, H., Gebremariam, Y., \& Jikamo, B. (2017). Improving Completeness of Inpatient Medical Records in Menelik II Referral Hospital, Addis Ababa, Ethiopia. Advances in Public Health, 2017, 1-5. doi:10.1155/2017/8389414

Wamukoya, J., and Mutula, S. M. (2005). E-Records Management and Governance in East and Southern Africa. Malaysian Journal of Library and Information Science, 10(2), 67-83.

West, A. F. (2002). Clinical decision-making: coping with uncertainty. Postgraduate Medical Journal, 78(920), 319-321. doi:10.1136/pmj.78.920.319.

Wong, R., Bradley, E. H., \& Hopkins, J. (2009). Medicine International, Johns Hopkins University, Baltimore, MD, USA, and Public Health, Yale School of Medicine, New Haven, CT, USA, Developing patient registration and medical records management system in Ethiopia, International Journal for Quality in Health Care; Volume 21, Number 4: pp. 253-258

Zegers, M., De Bruijne, M. C., Spreeuwenberg, P., Wagner, C., Groenewegen, P. P., \& Van der Wal, G. (2011). Quality of patient record keeping: an indicator of the quality of care? BMJ Quality \& Safety, 20(4), 314-318. doi:10.1136/bmjqs.2009.038976 